2014

\title{
Christian-Jewish Relations 1000-1300: Jews in the Service of Medieval Christendom
}

Devorah Schoenfeld

Loyola University Chicago, dschoenfeld@luc.edu

\section{Recommended Citation}

Schoenfeld, Devorah. "Christian-Jewish Relations 1000-1300: Jews in the Service of Medieval Christendom." Studies in ChristianJewish Relations, 9(1): 1-3.

This Book Review is brought to you for free and open access by the Faculty Publications at Loyola eCommons. It has been accepted for inclusion in Theology: Faculty Publications and Other Works by an authorized administrator of Loyola eCommons. For more information, please contact ecommons@luc.edu.

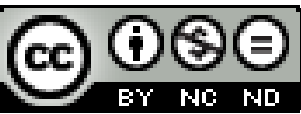

This work is licensed under a Creative Commons Attribution-Noncommercial-No Derivative Works 3.0 License.

(c) Boston College - Center for Christian-Jewish Learning, 2014. 


\section{REVIEW \\ Anna Sapir Abulafia \\ Christian-Jewish Relations 1000-1300: \\ Jews in the Service of Medieval Christendom}

(Harlow, England: Pearson, 2011), paperback, xxiv + 262 pp.

\section{Devorah Schoenfeld, Loyola University Chicago}

Abulafia's new work investigates the legal and literary trope of Jews as slaves, serfs, or servants in the Latin Christian world during the High Middle Ages. This trope, as Abulafia shows, mediates between two contradictory impulses in medieval Christian thought: on the one hand the sense that Jews ought to be protected because they represent something important in the Christian past, or are an important part of God's plan of salvation, or are in their subjection an important reminder of the truth of God's promises; and on the other the feeling that their very existence is dangerous to the unity and stability of Christendom. The trope of Jewish servitude, as Abulafia shows, is a tool that Christian thinkers developed for navigating between these two ideas about Jews and for finding them a role and a place in their society.

One of the fascinating and powerful insights of Abulafia's work is just how multivocal and ambiguous a trope this was, and how many different purposes it could be made to serve. The trope of Jewish servitude was used to protect Jews from persecution because they served a practical necessity. Alternatively, it was used to argue that Jews should be tolerated because they possess the virtue of being "prepared to serve," which Pope Alexander II argued was a virtue possessed by Jews and not Muslims (p. 139). Rulers who did not wish to tolerate Jews to the same extent could use the same trope to expel those who were not performing any particular service, as did England's King Henry III in 1290, or to simply assert it as their right to use the Jews as an expendable resource by expelling them and taking their money, as did Philip IV of France 
in 1306. When used by Christian theologians the trope of Jewish servitude was a way to justify toleration of Jews in a subordinate status, sometimes to pressure them to convert, as Rupert of Deutz argued, or to make it possible to solicit their help with Rabbinic scholarship as an alternative source for studying the Hebrew Bible.

As Abulafia shows, a paradox of this trope is that even when used explicitly to protect the Jews it could add another layer of anti-Judaic thinking. One fascinating example of this is Bernard of Clairvaux's argument that Jews should be tolerated because, by serving the Christian world as moneylenders, they keep Christians from themselves becoming moneylenders and thus committing the grave sin of usury. He argues for Jewish toleration but in the process situates the sin of usury as both particularly horrific and particularly Jewish.

The first two chapters of the book lay out the tensions around Jewish toleration in medieval Christendom and their origins. The first deals with the argument for toleration, based primarily on the views of Augustine, and the second deals with the argument for exclusion, focusing on the views of Pope Gregory the Great. The middle chapters, which form the heart of the book, take a close look at legal documents from Germany, France, England, and the Latin Mediterranean (such as Spain and Italy) to see the various ways that the idea of Jewish servitude was implemented in practice. Servitude, as Abulafia points out, does not necessarily mean subordination, and there were times when the trope of Jewish servitude gave Jews a position of privilege over many Christians in their society, as when Fredrick II of Germany used it to indicate that he would regard any attack on "his" Jews as an attack on himself. Yet the uses to which this trope was put continually varied, even, as Abulafia shows, within the reign of a single king.

The concluding two chapters look at the role of the trope of Jews as servants in two of the most horrific kinds of anti-Jewish persecutions in the medieval period: the massacres of Jews during the Crusades and the blood libels and the destruction 
they caused. During the Crusades, the trope of Jewish servitude could be used to distinguish Jews from Muslims by those (such as Bernard of Clairvaux) who wished to protect Jews while urging warfare against the Islamic world. In the blood libel, conversely, fictional stories about Jewish violence were made to serve Christian theological needs in ways that had terrible consequences for real Jews.

One counter-narrative that runs throughout is the Jewish response to this trope, which Abulafia finds in Jewish legal, pietistic, and liturgical texts. Many medieval Jews did not see themselves as servants of Christendom at all, but rather as dialogue partners, with the ability to reject Christian uses of their scholarship and to respond to Christian anti-Jewish polemics with a polemic of their own.

Abulafia's focus on the trope of Jewish servitude leads to some particular emphases in her reading of legal codes. She frequently touches on the question of whether or not Jews were permitted to hire non-Jewish servants or own Jewish slaves, which is important in thinking through the question of what Jewish servitude meant, since prohibiting Jews from owning slaves was a way of defining Jewish status as itself servile.

The book is written in an engaging, accessible style, although it might not be appropriate for undergraduates because of the background in Judaism and in medieval history that it assumes. It is recommended for advanced students and anyone who is interested in one of the formative tropes of medieval Jewish-Christian relations. 
Copyright of Studies in Christian-Jewish Relations is the property of Boston College Center for Christian-Jewish Learning and its content may not be copied or emailed to multiple sites or posted to a listserv without the copyright holder's express written permission. However, users may print, download, or email articles for individual use. 